\title{
Obituary: Dr Séamus Mac Suibhne (Sweeney) (1978-2019)
}

\author{
Brendan D. Kelly ${ }^{1} \cdot$ Kieran O'Loughlin ${ }^{2}$
}

Published online: 26 October 2019

(C) Royal Academy of Medicine in Ireland 2019

\begin{abstract}
Dr Séamus Mac Suibhne (Sweeney) (1978-2019) was a widely admired psychiatrist, writer and scholar whose contributions ranged from psychiatric care to Greek philosophy, and from medical education to the application of new technologies in educational and clinical settings. Séamus wrote extensively on these and many other themes in the professional and popular literature. In his clinical work, Séamus was a compassionate doctor, effective team-worker and skilled manager. He served as a representative of graduates on the Governing Authority of University College Dublin (2008-2013), secretary (2007-2009) and then president (2009-2014) of the Psychiatry Section of the Royal Academy of Medicine in Ireland, associate editor of the Irish Journal of Medical Science (2012-2019) and a member of the HSE National Shared Record Project. Séamus continuously wrote essays, book reviews, blogs and short stories, and won the 2010 Molly Keane Writing Prize. Philosophy was, perhaps, his greatest intellectual passion and he spoke and wrote extensively on themes linking philosophy with clinical care, the history of psychiatry and reflective practice in medicine. Séamus wrote and co-wrote on a range of other topics including psychiatric liaison with primary care, 'vampirism' as a mental illness, translation and interpretation in psychiatry, synaesthesia, 'new' mental illnesses such as solastalgia and hubris syndrome, bibliotherapy, the work of Nicholas Culpeper (a seventeenth-century English physician) and mental illness among psychiatrists. Séamus Mac Suibhne is deeply missed in Irish psychiatry, but his many contributions bear elegant, lasting testament to a dedicated family man, a gifted doctor and an enquiring, often brilliant mind.
\end{abstract}

Keywords Ireland · Medical education · Philosophy $\cdot$ Psychiatry

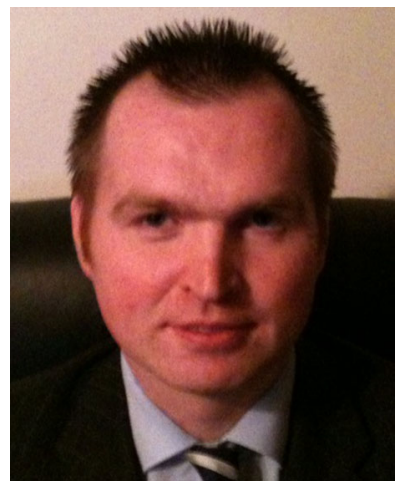

Dr Séamus Mac Suibhne (Sweeney) (1978-2019)

Brendan D. Kelly

brendan.kelly@tcd.ie

1 Department of Psychiatry, Trinity Centre for Health Sciences, Tallaght University Hospital, Tallaght Dublin 24 D24 NR0A Ireland

2 Department of Psychiatry, Tallaght University Hospital, Tallaght Dublin 24 D24 NR0A Ireland
Dr Séamus Mac Suibhne (Sweeney) (1978-2019) was a widely admired psychiatrist, writer and scholar whose contributions ranged from psychiatric care to Greek philosophy, and from medical education to the application of new technologies in educational and clinical settings. Over his career, Séamus wrote extensively on these and many other themes in the professional and popular literature. In his clinical work, Séamus was a compassionate doctor, effective team-worker and skilled manager. A dedicated family man with a profound love of nature, Séamus is deeply missed.

Séamus grew up Dublin and attended Blackrock College where he completed his Leaving Certificate in 1996. He studied medicine at University College Dublin (UCD) where he served as a committee member and auditor of UCD Philosophy Society and on the editorial board of the University Observer. In 1998, he was a member of the victorious UCD team on Challenging Times, the celebrated television quiz show. In 2001, Séamus won the undergraduate section of the Sheppard Memorial Prize, awarded by the Irish College of General Practitioners. Séamus graduated, MB BCh BAO (honours), in June 2002 and received a Special Award on the Faculty of Medicine's Dean's List and the 
UCD President's Award for Excellence in Extra-Curricular Activities.

Séamus worked as an intern in the Mater Misericordiae University Hospital, Dublin and St John's Hospital, Limerick. In July 2003, he started his training in psychiatry and held psychiatry registrar posts in Naas, Crumlin, St Patrick's University Hospital and child and adolescent psychiatry in Ballyfermot. In July 2006, Séamus became special lecturer in psychiatry at St Vincent's University Hospital, Dublin. In July 2007, he took up a post as senior (specialist) registrar and lecturer at St Vincent's and UCD. In July 2009, he became senior registrar in Ardee, County Louth.

Over these years, Séamus completed a Certificate in Humanities with the Open University (2003) and a Certificate in Neuropharmacology with the International College of Neuropsychopharmacology (2009). He gained membership of the Royal College of Psychiatrists in 2006 and won the Standish-Barry Prize, awarded for the highest marks obtained by an Irish trainee. In 2009, he completed a Postgraduate Diploma in Medical Education with the University of Dundee and went on to complete a Masters in Medical Education in June 2012. He also earned an MA in the Philosophy and Ethics of Mental Health from the University of Warwick in November 2010.

After completing his training in June 2010, Séamus worked as locum consultant psychiatrist in Cork University Hospital for 3 months and Ardee for 10 months. He took up a permanent post as consultant psychiatrist with the Health Service Executive (HSE) Carlow/Kilkenny/South Tipperary Mental Health Service in July 2011. In this position, Séamus not only led a multi-disciplinary team providing clinical care [1], but also chaired regular inter-departmental meetings in the hospital and took a lead in clinical audit, Schwartz rounds and local implementation of the HSE National Clinical Programme for the Assessment and Management of Patients Presenting to Emergency Departments Following Self Harm. Séamus was appointed senior clinical lecturer in psychiatry with the Royal College of Surgeons in Ireland, based in Kilkenny.

In his academic life, Séamus researched, wrote and cowrote about medical education [2-6] and had a particular interest in technology as a new and exciting element of both teaching and clinical care [7-9]. Séamus wrote extensively about philosophy $[10,11]$ and classic texts in the history of psychiatry [12-17], and had a particular interest in psychotherapy. Séamus's other contributions and co-authored papers concerned a dizzying array of topics including psychiatric liaison with primary care [18], 'vampirism' as a mental illness [19], translation and interpretation in psychiatry [20, 21], synaesthesia [22], 'new' mental illnesses such as solastalgia and hubris syndrome $[23,24]$, various aspects of psychiatric medication [25, 26], bibliotherapy [27] and the work of Nicholas Culpeper, a seventeenth-century English physician, herbalist, botanist and astrologer [28]. Séamus devoted particular attention to the need for better acknowledgement and management of mental illness among psychiatrists [29].

Séamus loved to read as well as write, and his range of interests was broad. He reviewed books and wrote on diverse themes for publications including the Guardian [30, 31], Times Literary Supplement [32-36], Lancet [37-39], Millennium: Journal of International Studies [40], Irish Journal of Psychological Medicine [41-44] and Spectator [45]. He also wrote short stories [46] and won the 2010 Molly Keane Writing Prize.

Séamus served as a member of the Senior Registrar Committee of the Irish Psychiatric Training Committee (2007-2009), a representative of UCD graduates on the UCD Governing Authority (2008-2013), secretary (2007-2009) and then president (2009-2014) of the Section of Psychiatry of the Royal Academy of Medicine in Ireland and associate editor of the Irish Journal of Medical Science (2012-2019). He was a member of the HSE National Shared Record Project and deeply involved with the Council of Clinical Information Officers as clinical lead for the Bipolar Lighthouse Project, an initiative within the eHealthIreland Ecosystem.

Alongside these myriad commitments, Séamus always prioritised time with his family, made space for his deep appreciation of the natural world, and maintained a keen interest in sport, even contributing to Newstalk's 'Off The Ball' sports programme on occasion. Séamus also blogged extensively, on both established blogs such as The Dabbler and blogs he created himself. He posted especially frequently on his personal blog, seamussweeney.net, which took its motto from Dante Alighieri's Divine Comedy: 'Poca favilla gran fiamma seconda'_-'A great flame follows a little spark'.

With Séamus, there were many sparks, and one great flame. An erudite and humble man, he is deeply missed.

Acknowledgements The authors acknowledge the generous assistance of Dr Aoife Ní Chorcoráin.

\section{Compliance with ethical standards}

Conflict of interest The authors declare that they have no conflict of interest.

Ethics approval This is not applicable.

Informed consent This is not applicable.

\section{References}

1. Brennan R (2018) Mammy, I don't want to die... The story of a little boy, Jake: his life, love and legacy. Orla Kelly Publisher, Dublin

2. Guerandel A, Mac Suibhne S, Malone K (2008) Best evidence medical education and psychiatry in Ireland: a three-step framework for change. Ir J Psychol Med 25:120-122. https://doi.org/ $10.1017 / \mathrm{S} 0790966700011204$ 
3. Mac Suibhne S, Guerandel A, Malone K (2007) 21st century psychiatry teaching for 21 st century doctors: how modern teaching methods may improve patient care. Ir Med J 100:484-486

4. Mac Suibhne SP (2010) Sophistry, the Sophists and modern medical education. Med Teach 32:71-75. https://doi.org/10.3109/ 01421590903386799

5. Mac Suibhne S (2012) Threshold concepts and teaching psychiatry: key to the kingdom or emperor's new clothes? Ir J Psychol Med 29: 132-134. https://doi.org/10.1017/S0790966700017456

6. Naughton M, Mac Suibhne S, Callanan I et al (2011) Quality of education at multidisciplinary case conferences in psychiatry. Int $\mathrm{J}$ Health Care Qual Assur 24:31-41. https://doi.org/10.1108/ 09526861111098229

7. Mac Suibhne S, Malone K, Guerandel A (2014) Network technologies in the medical education continuum. In: Trentin G (ed) Network-based continuing medical education: social media and professional development. Nova Science Publishers, Inc., New York, pp 193-206

8. Parvathaiah H, Daly C, Mac Suibhne S et al (2015) Development of e-learning module on delirium for non-consultant hospital doctors using the Delphi method. Eur Psychol 30(Suppl.1):997. https://doi. org/10.1016/S0924-9338(15)30782-3

9. Thompson S (2018) Mental health apps provide a head start for recovery. Irish Times (18 January)

10. Mac Suibhne S (2009) 'Wrestle to be the man philosophy wished to make you': Marcus Aurelius, reflective practitioner. Reflective Pract 10:429-436. https://doi.org/10.1080/14623940903138266

11. Sweeney S (2005) Homer. In: O'Grady PF (ed) Meet the philosophers of ancient Greece: everything you always wanted to know about ancient Greek philosophy but didn't know who to ask. Ashgate Publishing Limited, Aldershot, Hampshire, pp 15-20

12. Szasz T (1961) The myth of mental illness: foundations of a theory of personal conduct. Harper and Row, New York

13. Kelly BD, Bracken P, Cavendish H et al (2010) The myth of mental illness 50 years after publication: what does it mean today? Ir J Psychol Med 27:35-43. https://doi.org/10.1017/ S0790966700000902

14. Goffman E (1961) Asylums: essays on the social situation of mental patients and other inmates. Anchor Books, Doubleday and Company, New York

15. Mac Suibhne S (2009) Medical classics: Asylums: essays on the social situation of mental patients and other inmates. BMJ 339: b4109. https://doi.org/10.1136/bmj.b4109

16. Mac Suibhne S (2011) Erving Goffman's Asylums 50 years on. Br J Psychiatry 198:1-2. https://doi.org/10.1192/bjp.bp.109.077172

17. Adlam J, Gill I, Glackin SN, Kelly BD, Scanlon C, Mac Suibhne S (2013) Perspectives on Erving Goffman's 'Asylums' fifty years on. Med Health Care Philos 16:605-613. https://doi.org/10.1007/ s11019-012-9410-z

18. O'Reilly EA, Mac Suibhne S, Guerandel A (2010) General practitioners' attitudes to models of psychiatry-primary care liaison. Ir Med J 103:190

19. Mac Suibhne S, Kelly BD (2011) Vampirism as mental illness: myth, madness and the loss of meaning in psychiatry. Soc Hist Med 24:445-460. https://doi.org/10.1093/shm/hkq055

20. Mac Suibhne S, Ní Chorcoráin A (2008) 'I wish to speak to a psychiatrist, please': psychiatric vocabulary in phrase books. Psychiatr Bull 32:359. https://doi.org/10.1192/pb.32.9.359

21. Mac Suibhne S (2012) Interpreting in psychiatry: a clinician's perspective. Commentary on... The need for measurable standards in mental health interpreting. Psychiatrist 36:124-125. https://doi.org/ 10.1192/pb.bp.111.038117
22. Mac Suibhne S (2012) Hearing redness: qualia, synaesthesia and an empirical attempt to solve the mind-body problem. Brainchildren Press,Kilkenny

23. Mac Suibhne SP (2009) What makes 'a new mental illness'? The cases of solastalgia and hubris syndrome. Cosmos and History 5: 210-225

24. Mac Suibhne S (2012) A tale of two letters: doctors, the public, the media, and the evidence. Brainchildren Press, Kilkenny

25. Mac Suibhne S, Lyons D (2007) Discontinuation syndrome en masse. Ir J Psychol Med 24:42-44. https://doi.org/10.1017/ S079096670001017X

26. Mac Suibhne S, Giwa TA, McCauley MD (2010) Varencicline (champix)-associated manic relapse in bipolar affective disorder. Ir Med J 103:285-286

27. Mac Suibhne S, Abu OR (2014) Attitudes to and practice of bibliotherapy among senior trainees in psychiatry. Ir J Psychol Med 31: 107-110. https://doi.org/10.1017/ipm.2014.16

28. Mac Suibhne S (2010) Nicholas Culpeper, eels, and disulfiram. Alcohol Alcohol 45:589. https://doi.org/10.1093/alcalc/agq027

29. Mac Suibhne S, Ní Chorcoráin A, Lucey JV (2017) Acknowledging mental illness in psychiatrists. Int J Soc Psychiatry 63:561-562. https://doi.org/10.1177/ 0020764017726347

30. Sweeney S (2005) The mysterious bacillus. Guardian (5 February)

31. Sweeney S (2005) Bobbing about in Cork. Guardian (9 July)

32. Sweeney S (2017) Humans, being. Times Literary Supplement (15 February)

33. Sweeney S (2017) Born to fail. Times Literary Supplement (29 March)

34. Sweeney S (2017) Scrubs up well. Times Literary Supplement (19 July)

35. Sweeney S (2018) Blessing radishes. Times Literary Supplement (13 March)

36. Sweeney S (2019) Medicine. Times Literary Supplement (29 January)

37. Sweeney S (2000) Nabokov and lepidoptery in the life sciences. Lancet 355:939. https://doi.org/10.1016/S0140-6736(05)74151-9

38. Sweeney S (2001) The mystery of infinity. Lancet 357:564-565. https://doi.org/10.1016/S0140-6736(05)71720-7

39. Sweeney S (2001) The new New Thing. Lancet 357:402. https:// doi.org/10.1016/S0140-6736(05)71540-3

40. Sweeney S (2003) Book review: The contours of American politics and American politics and society today. Millennium 32:747-749

41. Mac Suibhne S (2008) Book review: The physician as patient: a clinical handbook for mental health professionals. Ir J Psychol Med 25:161. https://doi.org/10.1017/S079096670001137X

42. Mac Suibhne S (2011) Book review: Casebook of psychosomatic medicine. Ir J Psychol Med 28:174. https://doi.org/10.1017/ S0790966700012234

43. Mac Suibhne S (2012) Book review: Homesickness: an American history. Ir J Psychol Med 29:62-63. https://doi.org/10.1017/ S0790966700017663

44. Mac Suibhne S (2018) Book review: I know what you're thinking: brain imaging and mental privacy. Ir J Psychol Med 35:153-154. https://doi.org/10.1017/ipm.2016.7

45. Sweeney S (2004) Virtuous living. Spectator (4 December)

46. Sweeney S (2013) Five short stories. Brainchildren Publications, Kilkenny

Publisher's note Springer Nature remains neutral with regard to jurisdictional claims in published maps and institutional affiliations. 